\title{
THE RELATION ANALYSIS OF MARKETING MIX AND CUSTOMER PURCHASE OF COFFEE IN MALABAR MOUNTAIN CAFÉ IN BOGOR CITY
}

\author{
Ernalsalia Ateta, Ketut Budi Susrusa, and Gede Makse Korri Arisena \\ Agribusiness Study Program, Agriculture Faculty, Universitas Udayana, Jalan P.B. Sudirman, Denpasar, \\ Indonesia \\ Correspondence Email: atetajcd@gmail.com
}

Submitted 4 September 2020; Accepted 3 February 2021

\begin{abstract}
Penelitian ini bertujuan untuk mengetahui hubungan antara produk dengan keputusan pembelian konsumen kopi, harga dengan keputusan pembelian konsumen kopi, promosi dengan keputusan pembelian konsumen kopi dan lokasi dengan keputusan pembelian konsumen kopi. Penelitian dilakukan di Malabar Mountain Cafe di Kota Bogor pada bulan Mei sampai Oktober 2020. Sampel sebanyak 50 responden yang diambil dengan teknik nonprobability sampling. Data dikumpulkan dengan kuesioner yang kemudian dianalisis dengan menggunakan teknik analisis deskriptif dan analisis korelasi rank spearman dengan menggunakan software SPSS 23. Hasil penelitian menunjukkan bahwa produk memiliki hubungan yang kuat dengan keputusan pembelian konsumen kopi. Harga memiliki hubungan yang kuat dengan keputusan pembelian konsumen kopi. Promosi memiliki hubungan yang cukup kuat dengan keputusan pembelian konsumen kopi dan lokasi tidak berhubungan dengan keputusan pembelian konsumen kopi.
\end{abstract}

Kata kunci: kedai kopi, bauran pemasaran, keputusan pembelian konsumen

\section{ABSTRACT}

The aims of this research are finding out the correlation between product and consumer purchasing decisions, price and consumer purchasing decisions, promotion and consumer purchasing decisions, place and consumer purchasing decisions. This research has already done form May until October 2020. The samples were 50 respondents taken by nonprobability sampling technique. Data were collected by questionnaires. Data analysis were descriptive analysis technique and Spearman's Correlation analysis using SPSS 23 software. The results of this research shows the product is strongly related with coffee consumer purchasing decisions. The price is strongly related with coffee consumer purchasing decisions. The promotion is strong enough related with coffee consumer purchasing decisions and the place is not related with coffee consumer purchasing decisions.

Keywords: coffeeshop, marketing mix, purchasing decisions

\section{INTRODUCTION}

Coffee shops in Indonesia reached more than 2,950 outlets in August 2019. The number has increased almost tripled compared to 2016 that was only around 1,300 coffee shops (Toffin, 2019). Based on Toffin (2019), there are seven factors that drive the growth of coffee shop businesses in Indonesia based on research. First is the habit (culture) of hanging out while drinking coffee. Second is the increasing consumer purchasing power, growing middle class, and the price of RTD (Ready To Drink) Coffee in more affordable modern shops. Third is the dominance of the population of young Indonesians (Generation $\mathrm{Y}$ and $\mathrm{Z}$ ), that created a new lifestyle in consuming coffee. Fourth, social media also eases coffee shop entrepreneurs to carry out marketing and promotional activities. Fifth is 
the presence of ride hailing platforms (Grabfood and Gofood) that simplifies the sales process. Sixth is the low number of entries barriers in the coffee business supported by the availability of raw materials, equipment (coffee machines) and resources to build a coffee shop business. Seventh, the coffee shop business margin is relatively high.

Due to the factors, many new coffee shop brands currently have emerged and each of them is expansively opening tens to hundreds of branches in various cities to work on the young segment (students to first jobber). One of these cities is Bogor. The number of coffee shops in Bogor City in 2019 was 150 . The number of coffee shops in the City of Bogor is increasing significantly from year to year. Thus, it has an impact on the increasing competition in the coffee shop business in the City of Bogor.

In the midst of high competition for coffee shops in Bogor City, Malabar Mountain Café is present as an old coffee shop that has been existed since 2013. Malabar Mountain Café is a under the auspices of PT Sinar Mayang Lestari and it is affected by the emergence of a new coffee shop and busy coffee shop competition in Bogor city. It has an impact on the sales of Malabar Mountain Cafe coffee which has fluctuated (interview on 27 February 2020).

Even though it has been around for a long time and has its own advantages, Malabar Mountain Café has not been able to compete and become the leading coffee shop in Bogor City. Based on the coffee shop rankings (Tripadvisor, 2019), the superior coffee shops are Popolo Coffee, Baked \& Brewed Coffee, Ranin Coffee House, and Kemenady Coffee. To deal with these impacts and problems, Malabar Mountain Café is not just do nothing. Malabar Mountain Café has carried out a number of marketing activities including participating in various coffee festivals, joining the coffee community, holding cupping trips and being active in social media, that has a following of 5,182 people. This is conducted with the hope of attracting more consumers, making consumers buy coffee at Malabar Mountain Café and making Malabar Mountain Cafe a leading coffee shop in Bogor City. However, from the marketing activities that have been carried out, the manager of Malabar Mountain Café said that the program was carried out without identifying the Malabar Mountain Cafe target market, and they had never conducted an evaluation of its marketing mix. After the activity was carried out, Malabar Mountain Cafe also admitted that they had never evaluated the impact on consumer behavior in purchasing coffee.

According to Kotler (2002), the marketing mix is a set of marketing tools that companies use to continuously achieve their marketing goals in their target markets. Marketers generally use this marketing mix as a tool to obtain the response that companies want from their market for products offered by the company or to create purchases of company products. The marketing mix, especially the 4P (Product, Price, Promotion, and Place) is needed to affect consumers in making purchasing decisions. Based on this opinion, it can be concluded that the marketing mix is related to consumer purchasing decisions. However, research conducted by Desfita (2014) showed that Blackberry purchasing decisions, product mix and price have a relation with purchasing decisions. Meanwhile, place and promotion have no correlation with Blackberry purchasing decisions. This is due to the large number of respondents who do not make place and promotion variables as purchasing decisions.

Based on the description above, it is necessary to have a marketing strategy conducted by Malabar Mountain Café to maintain the existence as a local coffee shop in the midst of high competition in the city of Bogor. Therefore, the researcher wanted to examine more deeply about the implementation and relationship of the marketing mix, especially the 4P (Product, Price, Promotion, and Place) with coffee consumer purchasing decisions at Malabar Mountain Café. 


\section{RESEARCH METHOD}

This research was conducted from May to November 2020. It was conducted in Malabar Mountain Café located on Jalan Dr. Semeru, Kompleks Ruko Braja Mustika, no: 14, Bogor, 16111, West Java, Indonesia. Bogor city is designated as the research location because the number of coffee shops in the city continues to increase from year to year. Besides, there is intense competition between coffee shops in Bogor city. Malabar Mountain Café was chosen because the coffee shop's raw materials are obtained directly from its own garden and it is the only coffee shop in Bogor that sells Java Preanger Arabica coffee with a specialty grade.

The data used in this research were quantitative and qualitative data. The data used were from primary data in the form of distributing questionnaires to consumers. Secondary data in the research was literature study data from various scientific books and journals related to the marketing mix, purchasing decisions and coffee shops. The data collection method was in the form of interviews which also used a questionnaire and documentation.

Sampling in this research used technique of non-probability sampling. The sample selected in this research was based on convenience sampling technique, in which the researcher draws members of the population based on the ease with which they are found or the availability of members of certain populations only. Respondents were selected because of their presence at the "right time and place" where the research was being carried out (Maholtra, 2010). The determination of the number of samples in this research used the Roscoe theory formula. Roscoe's theory explained that if the research will carry out multivariate analysis (correlation or multiple regression), then the number of sample members is at least tenfold the number of variables under study. (Sugiyono, 2010). Thus, this research consisted of five variables. Thus, the number of samples is 5 times 10 , and 50 respondents were obtained. Respondents in this research were buyers of Malabar Mountain Café. Researchers obtained respondents by distributing questionnaires directly and online. For direct distribution of questionnaires, researchers came to Malabar Mountain Cafe to meet directly with consumers. For online distribution, researchers looked for respondents on Instagram and questionnaires were also distributed to coffee community groups assisted by the Malabar Mountain Café manager.

The research variables in this research consisted of the independent variable (independent variable) and the dependent variable (dependent variable). The dependent variables in this research were product, price, promotion and location. The dependent variable in this researcg the purchase decision. The purchase decision in this research was the tendency of consumers to take action to buy Malabar Mountain Cafe products.

Description of the marketing mix with the decision to purchase Malabar Mountain Cafe coffee used a Likert scale. The lowest scale was worth one that means strongly disagree and the highest scale was worth five that means strongly agree.

Operational limitations are research elements to measure a variable. Thus, it can be seen which indicators were the support of the variables to be analyzed. The operational limitations of the variables in this research are as follows:

1. The quality of taste in this research was the aroma and taste of coffee, such as sweet, fruity, sweet bright acid as typical of the consumer's expectations and desires.

2. The serving quantity used in this research was in the form of serving size, portion or volume (the glass used) Malabar Mountain Café in serving the coffee was in accordance with the expectations, desires of consumers and consumers are satisfied.

3. Flavor variation in this research was the variety of coffee variations based on taste 
and coffee processing methods from Malabar Mountain Café. The flavors in question were Latte, Cappuccino, Macchiatto. Meanwhile, the variation of coffee based on the coffee processing method is an espresso machine or manual brew (V60, French Press, Siphon, Vietnam Drip and Cold brew).

4. The cleanliness used in this research was the assurance of product cleanliness and the presentation of coffee at the Malabar Mountain Café.

5. The innovation in this research was the way of serving coffee, both appearance and coffee processing methods that follow current trends, such as serving coffee with latte art or literary packaged coffee.

6. The suitability of price with quality of taste in this research was to measure the price set by Malabar Mountain Cafe according to the quality of the coffee, such as the specialty grade coffee and consumers felt that the price was proportional to the quality of the taste enjoyed.

7. The suitability of price with benefits in this research was that the price set by Malabar Mountain Café. It made consumers felt that the benefits of the coffee obtained were greater than the price paid.

8. Affordability of prices in this research used to determine that the price set by the Malabar Mountain Café is purchased by consumers.

9. Price competitiveness in this research was used to determine consumer assessments regarding the price set by Malabar Mountain Café, which is the same or cheaper as other coffee shops.

10. Discount in this research was used to determine consumer interest in discounts given by Malabar Mountain Cafe.

11. The bonus in this research was used to determine consumer interest in the bonus given by Malabar Mountain Café.

12. The advertisement in this research was used to determine consumer interest in Malabar Mountain Café products that were actually on social media or internet sites owned by Malabar Mountain Café.
13. The affordability of the location in this research was to determine the strategic location of the Malabar Mountain Cafe and the availability of supporting facilities and infrastructure, such as public transportation or online motorcycle taxis.

14. Good access in this research was to determine or measure that the location of the Malabar Mountain Café was not located in a congestion area and could be reached within an estimated time in accordance with consumer expectations.

15. Proximity to residence in this research was to determine that Malabar Mountain Cafe consumers were in the same area as Malabar Mountain Cafe.

16. Product stability in this research was to measure consumer trust and confidence in the quality of coffee of Malabar Mountain Cafe whether it had been tested in accordance with the standards and requirements of specialty coffee and has been licensed by BPOM (Agency for Drug and Food Control).

17. The habit of purchasing products in this research was to measure the habits in purchasing coffee and the level of comfort and safety felt by consumers in making purchases at Malabar Mountain Café.

18. Recommending products to others in this research was to find out whether consumers will recommend and provide information about Malabar Mountain Café to others.

19. Repurchasing in this research was to determine the desire of consumers to repurchase and whether they were interested in trying new menu variations from Malabar Mountain Café.

In this research, a descriptive analysis was used to explain consumer characteristics consisting of the respondent's domicile, gender of the respondent, age of the respondent, occupation of the respondent, level of expenditure, frequency, how to purchase coffee and how to find out Malabar Mountain Cafe. 
Table 1. Interpretation of $r$ Value

\begin{tabular}{cc}
\hline Coefficient interval & Relationship level \\
\hline 0 & There is no correlation between the two variables \\
$>0-0,25$ & The correlation is very weak \\
$>0,25-0,5$ & Sufficient correlation \\
$>0,5-0,75$ & Strong correlation \\
$>0,75-0,99$ & The correlation is very strong \\
1 & Perfect correlation \\
\hline
\end{tabular}

Source: Sarwono \& Suhayati (2010)

This research used Rank Spearman correlation analysis to determine whether there was a relation between the marketing mix and purchasing decisions. Based on Sarwono and Suhayati (2010), Rank Spearman correlation is used to determine the relation between two ordinal scale variables, such as the independent variable and the dependent variable. The correlation analysis formula is (Sugiyono, 2013).

$$
\rho=1-\frac{6 \Sigma b_{i}^{2}}{n\left(n^{2}-1\right)}
$$

Information:

$\rho=$ Spearman Rank Correlation Coefficient

$\mathrm{b}=$ Difference in Variable Data Ranking

$\mathrm{n}=$ Number of Respondents

\section{RESULT AND DISCUSSION}

\section{Characteristic of Respondent}

The characteristics of the respondents in this research were obtained from the results of distributing closed questionnaires given to Malabar Mountain Café consumers. The characteristics of the respondent can be used to describe the condition or circumstances of the respondent that can provide additional information to understand the results of the research. The number of respondents in this research were 50 people, in which 33 respondents filled out questionnaires online and 17 respondents filled directly.

The characteristics of the most consumers of Malabar Mountain Café were

domiciled in Bogor city. This was due to the location of the Malabar Mountain Cafe located in Bogor. Thus, the respondents who made more purchases came from Bogor. Malabar Mountain Café's customers were predominantly male. This was in line with a survey conducted by HonestDocs, a health information platform which stated that men consume coffee more often than women. Most of Malabar Mountain Café's consumers were aged 25-35.

Hence, Malabar Mountain Cafe consumers were included in the young middle age category. Consumers who made purchases at Malabar Mountain Café mostly worked as private employees. This was supported because Malabar Mountain Café has joined the \#NgopidiKantor community, and so does TEMPO office. Besides, according to the Manager of Malabar Mountain Café, consumers who worked as private employees often came to Malabar Mountain Café for coffee during office breaks with their colleagues or for work meetings or just hanging out with their colleagues in their spare time.

Malabar Mountain Café's consumers had an average monthly expenditure of more than IDR 3,000,000. This number showed that Malabar Mountain Cafe consumers has a large income level, because the average consumer expenditure would describe the amount of purchasing power of a consumer. Malabar Mountain Cafe consumers had an average weekly coffee consumption rate of more than eight times. 
Table 2. Characteristics of Respondents at Malabar Mountain Cafe

\begin{tabular}{|c|c|c|}
\hline Information & Total & Percentage $(\%)$ \\
\hline \multicolumn{3}{|l|}{ Domicile } \\
\hline Bogor City & 30 & 60 \\
\hline Outside of Bogor City & 20 & 40 \\
\hline \multicolumn{3}{|l|}{ Sex } \\
\hline Male & 28 & 56 \\
\hline Female & 22 & 44 \\
\hline \multicolumn{3}{|l|}{ Age } \\
\hline$<25$ year & 10 & 20 \\
\hline $25-35$ year & 18 & 36 \\
\hline $36-45$ year & 16 & 32 \\
\hline$\geq 45$ year & 6 & 12 \\
\hline \multicolumn{3}{|l|}{ Job } \\
\hline Government employees & 6 & 12 \\
\hline Private employees & 19 & 38 \\
\hline Entrepreneur & 13 & 26 \\
\hline Student & 5 & 10 \\
\hline Others & 7 & 14 \\
\hline \multicolumn{3}{|l|}{ Average Expenditures } \\
\hline$<$ Rp1.000.000 & 5 & 10 \\
\hline Rp1.000.000 - Rp2.000.000 & 5 & 10 \\
\hline Rp2.000.000 - Rp3.000.000 & 9 & 18 \\
\hline$>\mathrm{Rp} 3.000 .000$ & 31 & 62 \\
\hline \multicolumn{3}{|c|}{ Frequency of Coffee Consumption per-Week } \\
\hline $1-2$ times & 11 & 22 \\
\hline $3-5$ times & 12 & 24 \\
\hline $6-8$ times & 9 & 18 \\
\hline$>8$ times & 18 & 36 \\
\hline \multicolumn{3}{|l|}{ How to Buy Coffee } \\
\hline Whatsapp & 20 & 40 \\
\hline Instagram (direct message) & 2 & 4 \\
\hline Come directly & 28 & 56 \\
\hline \multicolumn{3}{|c|}{ Knowing the Malabar Mountain Cafe } \\
\hline Family / Friends & 36 & 72 \\
\hline Social media & 1 & 2 \\
\hline Coffee Community & 9 & 18 \\
\hline Coffee Festival / Event & 2 & 4 \\
\hline Others & 2 & 4 \\
\hline
\end{tabular}

Source: Sarwono \& Suhayati (2010)

It showed that Malabar Mountain Café

knew Malabar Mountain Café for the first customers were people who really loved coffee and needed coffee.

They were not just following trends or friends. Currently, Malabar Mountain Cafe consumers make a lot of purchases by coming directly to Malabar Mountain Cafe and they time because of a recommendation from family or friends. This showed that there had been a WOM (Words of Mouth) activity among Malabar Mountain Cafe consumers. 
Table 3. Respondents' Assessment Toward the Products

\begin{tabular}{|c|c|c|c|c|c|c|c|c|}
\hline No & Statements & $\begin{array}{l}\text { STS } \\
\text { Fr } \\
(\%)\end{array}$ & $\begin{array}{l}\mathrm{TS} \\
\mathrm{Fr} \\
(\%)\end{array}$ & $\begin{array}{l}\mathrm{KS} \\
\mathrm{Fr} \\
(\%)\end{array}$ & $\begin{array}{c}\mathrm{S} \\
\mathrm{Fr} \\
(\%)\end{array}$ & $\begin{array}{c}\mathrm{SS} \\
\mathrm{Fr} \\
(\%)\end{array}$ & Mean & Category \\
\hline 1 & $\begin{array}{l}\text { The aroma of Malabar } \\
\text { Mountain Cafe coffee has a } \\
\text { distinctive aroma. }\end{array}$ & $\begin{array}{c}1 \\
(2)\end{array}$ & $\begin{array}{c}0 \\
(0)\end{array}$ & $\begin{array}{c}0 \\
(0)\end{array}$ & $\begin{array}{c}26 \\
(52)\end{array}$ & $\begin{array}{c}23 \\
(46)\end{array}$ & 4,40 & $\begin{array}{l}\text { Strongly } \\
\text { agree }\end{array}$ \\
\hline 2 & $\begin{array}{l}\text { The taste of Malabar } \\
\text { Mountain Cafe coffee is to } \\
\text { your liking. }\end{array}$ & $\begin{array}{c}1 \\
(2)\end{array}$ & $\begin{array}{c}0 \\
(0)\end{array}$ & $\begin{array}{c}2 \\
(4)\end{array}$ & $\begin{array}{c}24 \\
(48)\end{array}$ & $\begin{array}{c}23 \\
(46)\end{array}$ & 4,38 & $\begin{array}{l}\text { Strongly } \\
\text { agree }\end{array}$ \\
\hline 3 & $\begin{array}{l}\text { The taste of Malabar } \\
\text { Mountain Cafe coffee has a } \\
\text { distinctive taste. }\end{array}$ & $\begin{array}{c}0 \\
(0)\end{array}$ & $\begin{array}{c}0 \\
(0)\end{array}$ & $\begin{array}{c}2 \\
(4)\end{array}$ & $\begin{array}{c}22 \\
(44)\end{array}$ & $\begin{array}{c}26 \\
(52)\end{array}$ & 4,48 & $\begin{array}{l}\text { Strongly } \\
\text { agree }\end{array}$ \\
\hline 4 & $\begin{array}{l}\text { The size of the Malabar } \\
\text { Mountain Cafe coffee is in } \\
\text { accordance with your hopes } \\
\text { and desires. }\end{array}$ & $\begin{array}{c}0 \\
(0)\end{array}$ & $\begin{array}{c}0 \\
(0)\end{array}$ & $\begin{array}{c}2 \\
(4)\end{array}$ & $\begin{array}{c}23 \\
(46)\end{array}$ & $\begin{array}{c}25 \\
(50)\end{array}$ & 4,46 & $\begin{array}{c}\text { Strongly } \\
\text { agree }\end{array}$ \\
\hline 5 & $\begin{array}{l}\text { The portion / volume offered } \\
\text { by Malabar Mountain Cafe } \\
\text { makes you feel satisfied. }\end{array}$ & $\begin{array}{c}0 \\
(0)\end{array}$ & $\begin{array}{c}0 \\
(0)\end{array}$ & $\begin{array}{c}1 \\
(2)\end{array}$ & $\begin{array}{c}25 \\
(50)\end{array}$ & $\begin{array}{c}24 \\
(48)\end{array}$ & 4,46 & $\begin{array}{l}\text { Strongly } \\
\text { agree }\end{array}$ \\
\hline 6 & $\begin{array}{l}\text { Malabar Mountain Cafe has a } \\
\text { variety of coffee flavors. }\end{array}$ & $\begin{array}{c}0 \\
(0)\end{array}$ & $\begin{array}{c}1 \\
(2)\end{array}$ & $\begin{array}{c}4 \\
(8) \\
\end{array}$ & $\begin{array}{c}20 \\
(40)\end{array}$ & $\begin{array}{c}25 \\
(50)\end{array}$ & 4,38 & $\begin{array}{c}\text { Strongly } \\
\text { agree }\end{array}$ \\
\hline 7 & $\begin{array}{l}\text { The flavors offered by } \\
\text { Malabar Mountain Cafe are } \\
\text { your taste. }\end{array}$ & $\begin{array}{c}0 \\
0\end{array}$ & $\begin{array}{c}1 \\
(0)\end{array}$ & $\begin{array}{c}2 \\
(4)\end{array}$ & $\begin{array}{c}23 \\
(46)\end{array}$ & $\begin{array}{c}24 \\
(48)\end{array}$ & 4,40 & $\begin{array}{l}\text { Strongly } \\
\text { agree }\end{array}$ \\
\hline 8 & $\begin{array}{l}\text { The flavors of Malabar } \\
\text { Mountain Cafe coffee are } \\
\text { always complete. }\end{array}$ & $\begin{array}{c}0 \\
(0)\end{array}$ & $\begin{array}{l}2 \\
(4)\end{array}$ & $\begin{array}{c}6 \\
(12)\end{array}$ & $\begin{array}{c}24 \\
(48)\end{array}$ & $\begin{array}{c}18 \\
(36)\end{array}$ & 4,16 & Agree \\
\hline 9 & $\begin{array}{l}\text { Coffee flavors are always } \\
\text { available at Malabar Mountain } \\
\text { Cafe. }\end{array}$ & $\begin{array}{c}0 \\
(0)\end{array}$ & $\begin{array}{c}0 \\
(0)\end{array}$ & $\begin{array}{c}8 \\
(16)\end{array}$ & $\begin{array}{c}27 \\
(54)\end{array}$ & $\begin{array}{l}15 \\
(30)\end{array}$ & 4,14 & Agree \\
\hline 10 & $\begin{array}{l}\text { You believe in the cleanliness } \\
\text { of the Malabar Mountain Cafe } \\
\text { coffee products. }\end{array}$ & $\begin{array}{c}0 \\
(0)\end{array}$ & $\begin{array}{c}0 \\
(0)\end{array}$ & $\begin{array}{c}0 \\
(0)\end{array}$ & $\begin{array}{c}22 \\
(44)\end{array}$ & $\begin{array}{c}28 \\
(56)\end{array}$ & 4,56 & $\begin{array}{c}\text { Strongly } \\
\text { agree }\end{array}$ \\
\hline 11 & $\begin{array}{l}\text { You are satisfied with the } \\
\text { cleanliness of the Malabar } \\
\text { Mountain Cafe coffee. }\end{array}$ & $\begin{array}{c}0 \\
(0)\end{array}$ & $\begin{array}{c}0 \\
(0)\end{array}$ & $\begin{array}{c}1 \\
(2)\end{array}$ & $\begin{array}{c}22 \\
(44)\end{array}$ & $\begin{array}{c}27 \\
(54)\end{array}$ & 4,52 & $\begin{array}{c}\text { Strongly } \\
\text { agree }\end{array}$ \\
\hline 12 & $\begin{array}{l}\text { Malabar Mountain Cafe serves } \\
\text { coffee with new coffee } \\
\text { processing innovations. }\end{array}$ & $\begin{array}{c}0 \\
(0)\end{array}$ & $\begin{array}{c}0 \\
(0)\end{array}$ & $\begin{array}{c}8 \\
(16)\end{array}$ & $\begin{array}{c}27 \\
(54)\end{array}$ & $\begin{array}{l}15 \\
(30)\end{array}$ & 4,14 & Agree \\
\hline 13 & $\begin{array}{l}\text { The presentation of Malabar } \\
\text { Mountain Cafe coffee is in } \\
\text { accordance with current } \\
\text { trends. }\end{array}$ & $\begin{array}{c}0 \\
(0)\end{array}$ & $\begin{array}{c}1 \\
(2)\end{array}$ & $\begin{array}{c}8 \\
(16)\end{array}$ & $\begin{array}{c}25 \\
(50)\end{array}$ & $\begin{array}{c}16 \\
(32)\end{array}$ & 4,12 & Agree \\
\hline \multicolumn{7}{|c|}{ Average } & 4,35 & $\begin{array}{c}\text { Strongly } \\
\text { agree }\end{array}$ \\
\hline
\end{tabular}

Source: Primary Data (2020) 


\section{Respondents' Assessment toward The Products}

The respondent's assessment of the product variable was very agreeable.

It can be seen from the average value that was at the value of 4.35 , with the average value of this respondent's assessment in the interval of 4.21 - 5. This showed that the product variable was reflected in the indicator. quality of taste, quantity of serving, variety of flavors, cleanliness and innovation have met the needs and desires of consumers for coffee.

Malabar Mountain Café served quality coffee in accordance with the standards and requirements for specialty coffee, with a score of 80 to 89. The coffee of Malabar Mountain Café had a characteristic of sweet taste with a light level of fresh acid (sweet bright acid).

Malabar Mountain Cafe offered two different types of coffee based on the process, such as single process and blend process. The single process is formed from the post-harvest process of fresh red cherry seeds which consists of Natural, Honey, and Fully Wash coffee types. The process blend is formed from blending greenbeans from the Natural, Honey and Fully Wash processes with a certain composition. The process blend consists of two types of coffee, namely premium blends and specialty blends aimed for general consumers who are not used to consuming typical coffee from Malabar Mountain Cafe.

There were two types of coffee processing methods at Malabar Mountain Cafe, including machine and manual brew. Coffee processing used a machine, namely espresso, while manual brew is a coffee processing method using certain manual tools including French Press, Siphon, Vietnam Drip, V60 and Coldbrew. Malabar Mountain Café did not only sell coffee-based drinks, but also non-coffee drinks such as frozen greentea, milk and iced tea as well as snacks such as french fries and fried cassava.

Currently, the coffee that is most in demand by Malabar Mountain Café is Natural Coffee that tastes like fresh fruit, sour and sweet caramel. This brew from Natural
Coffee will make consumers feel fresh. Consumers will feel the acidity of the red grapes and also the sweet and sour taste that is calm but firm. Natural Coffee of Malabar Mountain Café has also received an award in Bangkok.

\section{Respondents' Assessment of Prices}

Respondents' assessment of the price variable was strongly agrees. It can be seen from the average value that was at the value of 4.36, with the average value of this respondent's assessment in the interval 4.21 5 . This price variable was reflected by the indicator of price suitability with quality, the suitability of price with benefits, affordability and price competitiveness indicate that the selling price of coffee set by Malabar Mountain Café was in accordance with the expectations and conditions of its consumers.

Malabar Mountain Café should Malabar Arabica coffee in two forms of coffee, namely roastedbeans coffee and liquid coffee (Ready to Drink). In determining the selling price of coffee in the form of roasted beans, Malabar Mountain Cafe by calculated production costs (HPP/Cost of goods sold) including cultivation costs, post-harvest processing costs, transportation costs to packaging costs.

In determining the selling price of coffee in the form of ready-to-drink coffee, it is sold by calculating the cost of production (HPP/Cost of goods sold) that included raw material costs, supporting material costs, labor costs and overhead costs.

The price set by Malabar Mountain Café is considered to be competitive because it is considered to be in accordance with the quality of the coffee provided. Malabar Mountain Café coffee was in a specialty grade that was processed from upstream to downstream. It was capable to produce the best coffee taste.

\section{Respondents' Assessment of Promotion}

The average value of the respondent's assessment of the promotion variable was 3.40. it was in the disagree category. 
Table 4. Respondents' Assessment of Prices

\begin{tabular}{|c|c|c|c|c|c|c|c|c|}
\hline & & STS & TS & KS & $\mathrm{S}$ & SS & & \\
\hline No & Statements & $\begin{array}{c}\mathrm{Fr} \\
(\%)\end{array}$ & $\begin{array}{l}\mathrm{Fr} \\
(\%)\end{array}$ & $\begin{array}{c}\mathrm{Fr} \\
(\%)\end{array}$ & $\begin{array}{l}\mathrm{Fr} \\
(\%)\end{array}$ & $\begin{array}{c}\mathrm{Fr} \\
(\%)\end{array}$ & Mean & Category \\
\hline 1 & $\begin{array}{l}\text { The price you pay is according } \\
\text { to the quality of the coffee } \\
\text { taste served. }\end{array}$ & $\begin{array}{c}0 \\
(0)\end{array}$ & $\begin{array}{c}0 \\
(0)\end{array}$ & $\begin{array}{c}0 \\
(0)\end{array}$ & $\begin{array}{c}28 \\
(56)\end{array}$ & $\begin{array}{c}22 \\
(44)\end{array}$ & 4,44 & $\begin{array}{c}\text { Strongly } \\
\text { agree }\end{array}$ \\
\hline 2 & $\begin{array}{l}\text { The price you pay is } \\
\text { proportional to the quality of } \\
\text { the coffee you enjoy. }\end{array}$ & $\begin{array}{c}0 \\
(0)\end{array}$ & $\begin{array}{c}0 \\
(0)\end{array}$ & $\begin{array}{c}0 \\
(0)\end{array}$ & $\begin{array}{c}23 \\
(46)\end{array}$ & $\begin{array}{c}27 \\
(54)\end{array}$ & 4,54 & $\begin{array}{c}\text { Strongly } \\
\text { agree }\end{array}$ \\
\hline 3 & $\begin{array}{l}\text { The price of coffee at Malabar } \\
\text { Mountain Cafe is in } \\
\text { accordance with the benefits } \\
\text { of the coffee products you get. }\end{array}$ & $\begin{array}{c}0 \\
(0)\end{array}$ & $\begin{array}{c}0 \\
(0)\end{array}$ & $\begin{array}{c}1 \\
(2)\end{array}$ & $\begin{array}{c}30 \\
(60)\end{array}$ & $\begin{array}{c}19 \\
(38)\end{array}$ & 4,36 & $\begin{array}{c}\text { Strongly } \\
\text { agree }\end{array}$ \\
\hline 4 & $\begin{array}{l}\text { You feel the benefits of } \\
\text { Malabar Mountain Cafe coffee } \\
\text { are greater than the money. }\end{array}$ & $\begin{array}{c}0 \\
(0)\end{array}$ & $\begin{array}{c}2 \\
(4)\end{array}$ & $\begin{array}{c}5 \\
(10)\end{array}$ & $\begin{array}{c}28 \\
(56)\end{array}$ & $\begin{array}{c}15 \\
(30)\end{array}$ & 4,12 & Agree \\
\hline 5 & $\begin{array}{l}\text { The price offered by Malabar } \\
\text { Mountain Cafe is affordable } \\
\text { for you. }\end{array}$ & $\begin{array}{c}0 \\
(0)\end{array}$ & $\begin{array}{c}0 \\
(0)\end{array}$ & $\begin{array}{c}1 \\
(0)\end{array}$ & $\begin{array}{c}29 \\
(58)\end{array}$ & $\begin{array}{c}20 \\
(40)\end{array}$ & 4,38 & $\begin{array}{c}\text { Strongly } \\
\text { agree }\end{array}$ \\
\hline 6 & $\begin{array}{l}\text { The price offered by Malabar } \\
\text { Mountain Cafe is according to } \\
\text { your abilities. }\end{array}$ & $\begin{array}{c}0 \\
(0)\end{array}$ & $\begin{array}{c}0 \\
(0)\end{array}$ & $\begin{array}{c}0 \\
(0)\end{array}$ & $\begin{array}{c}32 \\
(64)\end{array}$ & $\begin{array}{c}18 \\
(36)\end{array}$ & 4,36 & $\begin{array}{c}\text { Strongly } \\
\text { agree }\end{array}$ \\
\hline 7 & $\begin{array}{l}\text { The price of Malabar } \\
\text { Mountain Cafe is able to } \\
\text { compete with other coffee } \\
\text { shops. }\end{array}$ & $\begin{array}{c}0 \\
(0)\end{array}$ & $\begin{array}{l}1 \\
(2)\end{array}$ & $\begin{array}{c}3 \\
(6)\end{array}$ & $\begin{array}{c}23 \\
(46)\end{array}$ & $\begin{array}{c}23 \\
(46)\end{array}$ & 4,36 & $\begin{array}{c}\text { Strongly } \\
\text { agree }\end{array}$ \\
\hline \multicolumn{7}{|c|}{ Average } & 4,36 & $\begin{array}{c}\text { Strongly } \\
\text { agree }\end{array}$ \\
\hline
\end{tabular}

Source: Primary Data (2020)

This showed that consumers did not agree with promotional activities as reflected by indicators in the form of bonuses, price discounts and advertising activities that could attract consumers to buy coffee products at Malabar Mountain Café.

The bonus was given at the coffee exhibition. Activities carried out during the exhibition were displaying Malabar Mountain Café arabica coffee from several processing processes, demonstrations and presentations of coffee making using manual brew processes in which the coffee drinks were distributed to consumers at the exhibition.

Discounts were given when Malabar Mountain Café released a new product. This aimed to introduce the new Malabar coffee product to consumers with hope that consumers would also repurchase later.

Malabar Mountain Café conducted advertising activities by creating a personal website that contained information about the company PT Sinar Mayang Lestari, how to plant it, and about the Malabar Mountain Café's coffee shop. Malabar Mountain Café was also active on the Facebook page contained various products, information about products and reviews from consumers.

Malabar Mountain Cafe also has an Instagram account to introduce and display information about coffee at @Malabarmountaincoffee and coffee shop activities at@Malabarmountaincafe. 
Table 5. Respondents' Assessment of Promotion

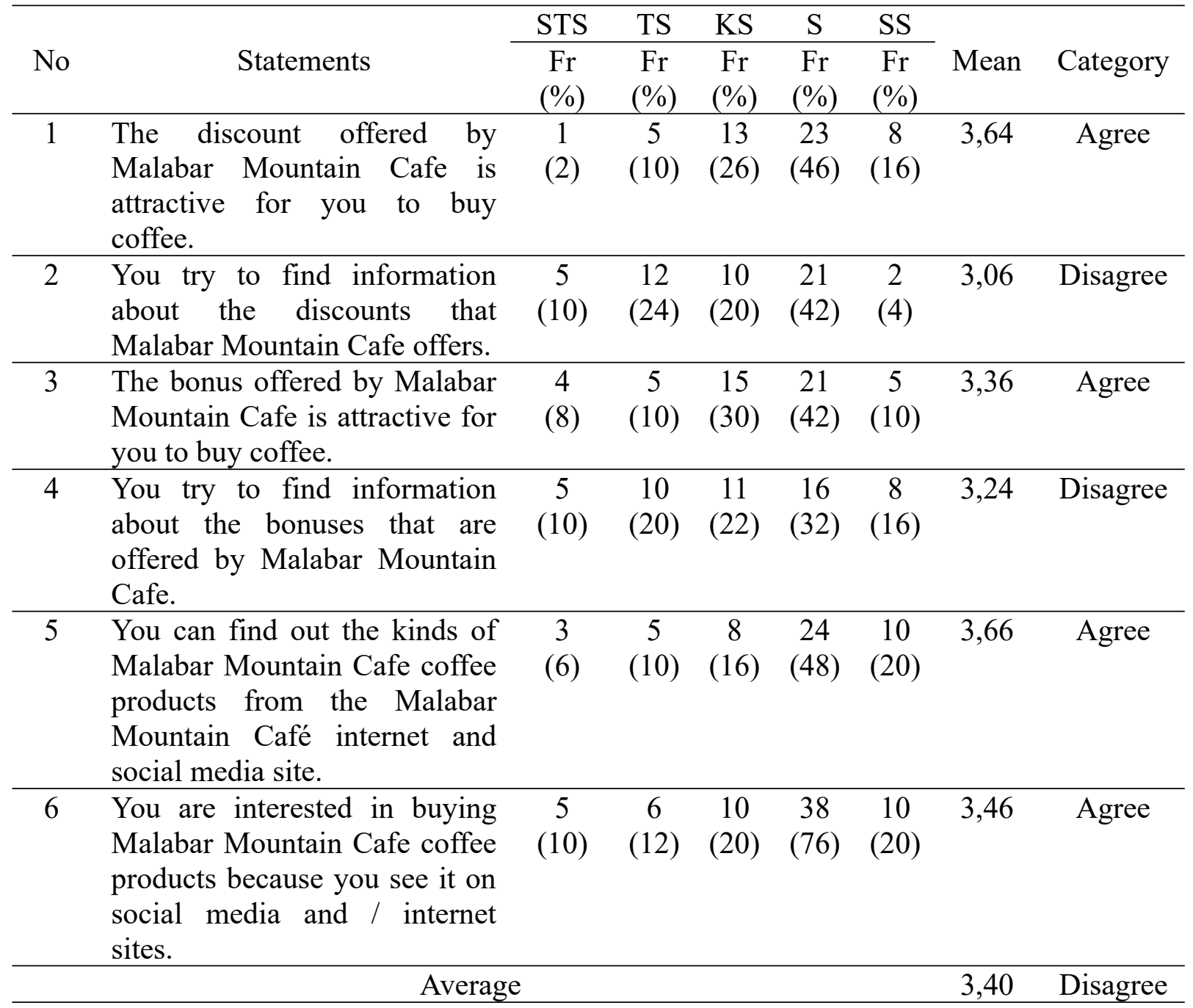

Source: Primary Data (2020)

Consumers can find information about coffee and/or coffee shops in the two Instagram accounts, such as information on exhibition activities, talk shows or other activities such as field trips. For the Instagram account@Malabarmountaincoffee has been followed by 5,201 people and for the Instagram account@Malabarmountaincafe has been followed by 1,063 people. This is one of the opportunities for Malabar Mountain Cafe to promote products that are sold to consumers.

\section{Respondents' Assessment of Location}

The average value of the respondent's assessment of the location variable was 3.42 that was in the agree category. It showed that consumers agreed with the location variable reflected by indicators of location affordability, easy access and proximity to the consumer's residence on purchasing decisions.

The location of Malabar Mountain Café can be said to be strategic because it is on the side of a big road in Bogor City which is widely traversed by vehicles. Thus, it is easy to find and access to the location is also easy. There are also supporting facilities and infrastructure, such as online motorcycle taxis, public transportation, and not far from the station. 
Table 6. Respondents' Assessment of Location

\begin{tabular}{|c|c|c|c|c|c|c|c|c|}
\hline No & Statements & $\begin{array}{c}\text { STS } \\
\text { Fr } \\
(\%) \\
\end{array}$ & $\begin{array}{l}\mathrm{TS} \\
\mathrm{Fr} \\
(\%)\end{array}$ & $\begin{array}{c}\mathrm{KS} \\
\mathrm{Fr} \\
(\%)\end{array}$ & $\begin{array}{c}\mathrm{S} \\
\mathrm{Fr} \\
(\%)\end{array}$ & $\begin{array}{c}\mathrm{SS} \\
\mathrm{Fr} \\
(\%)\end{array}$ & Mean & Category \\
\hline 1 & $\begin{array}{l}\text { The location of Malabar } \\
\text { Mountain Cafe is easy to reach } \\
\text { from your location. }\end{array}$ & $\begin{array}{c}0 \\
0\end{array}$ & $\begin{array}{l}3 \\
(6)\end{array}$ & $\begin{array}{c}11 \\
(22)\end{array}$ & $\begin{array}{c}20 \\
(40)\end{array}$ & $\begin{array}{l}16 \\
(32)\end{array}$ & 2,98 & Disagree \\
\hline 2 & $\begin{array}{l}\text { The location of Malabar } \\
\text { Mountain Cafe is far from } \\
\text { congestion. }\end{array}$ & $\begin{array}{c}0 \\
(0)\end{array}$ & $\begin{array}{c}4 \\
(8)\end{array}$ & $\begin{array}{c}16 \\
(32)\end{array}$ & $\begin{array}{c}20 \\
(40)\end{array}$ & $\begin{array}{l}10 \\
(20)\end{array}$ & 3,72 & Agree \\
\hline 3 & $\begin{array}{l}\text { Malabar Mountain Cafe is close } \\
\text { to your home. }\end{array}$ & $\begin{array}{c}6 \\
(12)\end{array}$ & $\begin{array}{c}13 \\
(26)\end{array}$ & $\begin{array}{c}7 \\
(14)\end{array}$ & $\begin{array}{c}13 \\
(26)\end{array}$ & $\begin{array}{c}11 \\
(22)\end{array}$ & 3,20 & Disagree \\
\hline 4 & $\begin{array}{l}\text { The location of Malabar } \\
\text { Mountain Cafe and your house is } \\
\text { in the same area. }\end{array}$ & $\begin{array}{c}12 \\
(24)\end{array}$ & $\begin{array}{c}9 \\
(18)\end{array}$ & $\begin{array}{c}6 \\
(12)\end{array}$ & $\begin{array}{l}16 \\
(32)\end{array}$ & $\begin{array}{c}7 \\
(14)\end{array}$ & 2,94 & Disagree \\
\hline 5 & $\begin{array}{l}\text { From your location to Malabar } \\
\text { Mountain Cafe, it can be reached } \\
\text { within an estimated time that } \\
\text { suits your expectations. }\end{array}$ & $\begin{array}{c}2 \\
(4)\end{array}$ & $\begin{array}{c}6 \\
(12)\end{array}$ & $\begin{array}{c}10 \\
(20)\end{array}$ & $\begin{array}{c}23 \\
(46)\end{array}$ & $\begin{array}{c}9 \\
(18)\end{array}$ & 3,62 & Agree \\
\hline 6 & $\begin{array}{l}\text { For those of you, supporting } \\
\text { facilities and infrastructure such } \\
\text { as public transportation / online } \\
\text { motorcycle taxis at the Malabar } \\
\text { Mountain Cafe location are } \\
\text { adequate. }\end{array}$ & $\begin{array}{c}0 \\
0 \\
(0)\end{array}$ & $\begin{array}{l}3 \\
(6)\end{array}$ & $\begin{array}{c}5 \\
(10)\end{array}$ & $\begin{array}{c}26 \\
(52)\end{array}$ & $\begin{array}{c}1 \\
(2)\end{array}$ & 4,10 & Agree \\
\hline
\end{tabular}

Source: Primary Data (2020)

\section{Respondents' Assessment of Purchasing Decisions}

The average value of the consumer purchasing decision variable assessment was 4.43 and it was in the strongly agree category. This showed that the indicators reflected in the purchasing decision variable had given consumers a strong sense of confidence and convinced that the purchasing decision for a product taken was correct. This respondent's assessment was in line with the quality of Malabar Mountain Café coffee products that had been tested according to the standards and provisions of specialty coffee and had been licensed by BPOM. Thus, consumers were comfortable, they felt safe and they would recommend it to others and would repurchase coffee products from Malabar Mountain Café.

\section{Results of the Spearman Rank Correlation Analysis}

The relation studied included the $4 \mathrm{P}$ marketing mix, such as product, price, promotion and location with consumer purchasing decisions. To determine the relation between product (X1), price (X2), promotion (X3) and location (X4) with consumer purchasing decisions (Y) at Malabar Mountain Cafe in Bogor City, it would be tested with the Spearman rank correlation test. It was because based on Sarwono and Suhayati (2010). Rank Spearman correlation was used to determine the relationship between two ordinal scale variables, namely the independent variable and the dependent variable. This spearman rank correlation analysis used the IBM SPSS 23 program. 
Tabel 7. Respondents' Assessment of Purchasing Decision

\begin{tabular}{|c|c|c|c|c|c|c|c|c|}
\hline \multirow[b]{2}{*}{ No } & \multirow[b]{2}{*}{ Statements } & STS & $\mathrm{TS}$ & $\mathrm{KS}$ & $\mathrm{S}$ & $\mathrm{SS}$ & \multirow[b]{2}{*}{ Mean } & \multirow[b]{2}{*}{ Category } \\
\hline & & $\begin{array}{l}\mathrm{Fr} \\
(\%)\end{array}$ & $\begin{array}{l}\mathrm{Fr} \\
(\%)\end{array}$ & $\begin{array}{l}\mathrm{Fr} \\
(\%)\end{array}$ & $\begin{array}{l}\mathrm{Fr} \\
(\%)\end{array}$ & $\begin{array}{l}\mathrm{Fr} \\
(\%)\end{array}$ & & \\
\hline 1 & $\begin{array}{l}\text { You believe in the quality of } \\
\text { Malabar Mountain Cafe coffee } \\
\text { products. }\end{array}$ & $\begin{array}{c}0 \\
(0)\end{array}$ & $\begin{array}{c}0 \\
(0)\end{array}$ & $\begin{array}{c}0 \\
(0)\end{array}$ & $\begin{array}{c}23 \\
(46)\end{array}$ & $\begin{array}{c}27 \\
(54)\end{array}$ & 4,54 & $\begin{array}{l}\text { Strongly } \\
\text { agree }\end{array}$ \\
\hline 2 & $\begin{array}{l}\text { You believe that the quality of } \\
\text { Malabar Mountain Cafe coffee } \\
\text { products has been tested. }\end{array}$ & $\begin{array}{c}0 \\
(0)\end{array}$ & $\begin{array}{c}0 \\
(0)\end{array}$ & $\begin{array}{c}0 \\
(0)\end{array}$ & $\begin{array}{c}22 \\
(44)\end{array}$ & $\begin{array}{c}28 \\
(56)\end{array}$ & 4,56 & $\begin{array}{l}\text { Strongly } \\
\text { agree }\end{array}$ \\
\hline 3 & $\begin{array}{l}\text { You feel comfortable and safe } \\
\text { when making purchases at } \\
\text { Malabar Mountain Cafe. }\end{array}$ & $\begin{array}{c}0 \\
(0)\end{array}$ & $\begin{array}{c}0 \\
(0)\end{array}$ & $\begin{array}{c}0 \\
(0)\end{array}$ & $\begin{array}{c}24 \\
(48)\end{array}$ & $\begin{array}{c}26 \\
(52)\end{array}$ & 4,52 & $\begin{array}{l}\text { Strongly } \\
\text { agree }\end{array}$ \\
\hline 4 & $\begin{array}{l}\text { You buy Malabar Mountain } \\
\text { Cafe coffee because the people } \\
\text { closest to you usually buy it. }\end{array}$ & $\begin{array}{c}2 \\
(4)\end{array}$ & $\begin{array}{c}3 \\
(6)\end{array}$ & $\begin{array}{c}10 \\
(20)\end{array}$ & $\begin{array}{c}23 \\
(46)\end{array}$ & $\begin{array}{c}12 \\
(24)\end{array}$ & 3,80 & Agree \\
\hline 5 & $\begin{array}{l}\text { You will recommend Malabar } \\
\text { Mountain Cafe coffee to your } \\
\text { friends and family. }\end{array}$ & $\begin{array}{c}0 \\
(0)\end{array}$ & $\begin{array}{c}0 \\
(0)\end{array}$ & $\begin{array}{c}0 \\
(0)\end{array}$ & $\begin{array}{c}23 \\
(46)\end{array}$ & $\begin{array}{c}27 \\
(54)\end{array}$ & 4,54 & $\begin{array}{c}\text { Strongly } \\
\text { agree }\end{array}$ \\
\hline 6 & $\begin{array}{l}\text { You will provide information } \\
\text { about Malabar Mountain Cafe } \\
\text { coffee to other people. }\end{array}$ & $\begin{array}{c}0 \\
(0)\end{array}$ & $\begin{array}{c}0 \\
(0)\end{array}$ & $\begin{array}{c}0 \\
(0)\end{array}$ & $\begin{array}{c}22 \\
(44)\end{array}$ & $\begin{array}{c}28 \\
(56)\end{array}$ & 4,56 & $\begin{array}{l}\text { Strongly } \\
\text { agree }\end{array}$ \\
\hline 7 & $\begin{array}{l}\text { You are interested in } \\
\text { repurchasing coffee at Malabar } \\
\text { Mountain Cafe. }\end{array}$ & $\begin{array}{c}0 \\
(0)\end{array}$ & $\begin{array}{c}0 \\
(0)\end{array}$ & $\begin{array}{c}0 \\
(0)\end{array}$ & $\begin{array}{c}21 \\
(42)\end{array}$ & $\begin{array}{c}29 \\
(58)\end{array}$ & 4,58 & $\begin{array}{l}\text { Strongly } \\
\text { agree }\end{array}$ \\
\hline 8 & $\begin{array}{l}\text { You intend to try other new } \\
\text { variations of coffee that } \\
\text { Malabar Mountain Cafe has to } \\
\text { offer. }\end{array}$ & $\begin{array}{c}1 \\
(2)\end{array}$ & $\begin{array}{c}0 \\
(0)\end{array}$ & $\begin{array}{c}2 \\
(4)\end{array}$ & $\begin{array}{c}24 \\
(48)\end{array}$ & $\begin{array}{c}23 \\
(46)\end{array}$ & 4,36 & $\begin{array}{c}\text { Strongly } \\
\text { agree }\end{array}$ \\
\hline & Averag & & & & & & 4,43 & $\begin{array}{c}\text { Strongly } \\
\text { agree }\end{array}$ \\
\hline
\end{tabular}

Source: Primary Data (2020)

Table 8 shows that the product variable had a strong and significant relation with coffee consumer purchasing decisions. The correlation coefficient value was 0.736 and the significance value was 0.000 (p $<0.01)$. Thus, it can be interpreted that the more the product mix was improved, the consumer's purchasing decisions would also increase. With the existence of a relation between the product and coffee consumer purchasing decisions, it indicated that the product was reflected by the indicator of taste quality. It indicated that the more Malabar Mountain Cafe maintained the quality by selling coffee with good grade coffee, the

consumer purchasing decisions would increase.

The products in this research were also reflected by the serving quantity indicator that showed that the more various sizes of cups (small, medium, and large) were provided in serving coffee, the more consumer purchasing decisions were made.

Products reflected by indicators of flavor variations indicated the increasing number of flavors of coffee that Malabar Mountain Cafe sold. They were not limited to variations of latte, cappuccino, machiato, it would further increase consumer purchasing decisions. 
Table 8. Marketing Mix Correlation Test Results with Consumer Purchasing Decisions

\begin{tabular}{|c|c|c|c|c|c|c|}
\hline \multicolumn{2}{|c|}{ Description } & \multirow{2}{*}{$\begin{array}{c}\text { Product } \\
1,000\end{array}$} & \multirow{2}{*}{$\frac{\text { Price }}{, 698^{* *}}$} & \multirow{2}{*}{$\frac{\text { Promotion }}{, 336^{*}}$} & \multirow{2}{*}{$\begin{array}{c}\text { Location } \\
-, 122\end{array}$} & \multirow{2}{*}{$\begin{array}{c}\text { Purchasing } \\
\text { Decision }\end{array}$} \\
\hline Product & $\begin{array}{l}\text { Correlation } \\
\text { Coefficient }\end{array}$ & & & & & \\
\hline \multirow{4}{*}{ Price } & Sig. (2-tailed) & . & ,000 & 017 & ,398 &, 000 \\
\hline & $\mathrm{N}$ & 50 & 50 & 50 & 50 & 50 \\
\hline & $\begin{array}{l}\text { Correlation } \\
\text { Coefficient }\end{array}$ &, $698^{* *}$ & 1,000 & ,220 &,- 138 &, $595^{* *}$ \\
\hline & Sig. (2-tailed) & $\begin{array}{c}, 000 \\
50\end{array}$ & 50 & $\begin{array}{c}125 \\
50\end{array}$ & $\begin{array}{c}, 339 \\
50\end{array}$ & $\begin{array}{c}, 000 \\
50\end{array}$ \\
\hline \multirow[t]{2}{*}{ Promotion } & $\begin{array}{l}\text { Correlation } \\
\text { Coefficient }\end{array}$ &, $336^{*}$ & ,220 & 1,000 &, 043 &, $353^{*}$ \\
\hline & $\begin{array}{c}\text { Sig. (2-tailed) } \\
\text { N }\end{array}$ & $\begin{array}{c}, 017 \\
50\end{array}$ & $\begin{array}{c}125 \\
50\end{array}$ & 50 & $\begin{array}{c}, 765 \\
50\end{array}$ & $\begin{array}{c}, 012 \\
50\end{array}$ \\
\hline \multirow[t]{2}{*}{ Location } & $\begin{array}{l}\text { Correlation } \\
\text { Coefficient }\end{array}$ &,- 122 &,- 138 &, 043 & 1,000 &,- 099 \\
\hline & $\begin{array}{c}\text { Sig. (2-tailed) } \\
\text { N }\end{array}$ & $\begin{array}{c}, 398 \\
50\end{array}$ & $\begin{array}{c}, 339 \\
50\end{array}$ & $\begin{array}{c}765 \\
50\end{array}$ & 50 & $\begin{array}{c}, 496 \\
50\end{array}$ \\
\hline \multirow[t]{2}{*}{$\begin{array}{l}\text { Purchasing } \\
\text { Decision }\end{array}$} & $\begin{array}{l}\text { Correlation } \\
\text { Coefficient }\end{array}$ &, $736^{* *}$ &, $595^{* *}$ &, $353^{*}$ &,- 099 & 1,000 \\
\hline & Sig. (2-tailed) & $\begin{array}{r}, 000 \\
50\end{array}$ & $\begin{array}{r}, 000 \\
50\end{array}$ & $\begin{array}{ll}, 012 & \\
& \end{array}$ & $\begin{array}{r}, 496 \\
50\end{array}$ & 50 \\
\hline
\end{tabular}

Source: Primary Data (2020)

Furthermore, products reflected in hygiene indicators showed that the product cleanliness and the way coffee was served at Malabar Mountain Cafe would further improve consumer purchasing decisions. Maintaining cleanliness was like adding trash bins, adding a sink for washing hands, chairs and tables that must be clean from dust or crust from coffee or food.

Products reflected by innovation indicators showed that the more innovations Malabar Mountain Cafe created in the presentation and processing of the coffee, the more consumer purchasing decisions will be. The innovations were such as increasing the number of innovations in flavor variations, innovations in the presentation of coffee (latte art), and innovations in packaging to make it even more attractive.

Based on the results of this research, the product mix was important for Malabar Mountain Café consumers in making purchasing decisions. Malabar Mountain Café was expected to be able to improve all aspects related to products, in terms of quality, quantity, variety, cleanliness and innovation, thus, consumer purchasing decisions also increased.

This research also explained that all indicators that represent the product had fulfilled consumer desires and encouraged consumers to make purchases. The results of this research were also in line with the opinion of Prayogo and Lumowa (2008) that the product is the elements of the marketing mix that can satisfy or fulfill the needs and desires of consumers. Through the purchase of these products, consumers can fulfill their satisfaction. If satisfaction is created there will be a repurchase.

The price variable had a strong and significant relation with coffee consumer purchasing decisions. The correlation coefficient value was 0.595 and the significance value was $0.000(\mathrm{p}<0.01)$. Thus, it can be interpreted that the more the price mix is increased, the consumer's purchasing decisions will also increase. The price mix 
indicator used in this research covered price affordability with taste quality, price compatibility with benefits, price affordability and price competitiveness. Thus, the price reflected by the indicator of price affordability with the quality of taste showed that the more appropriate and according to the Malabar Mountain Café set the price, the consumer's purchasing decision would increase.

In this research, the price was reflected by the indicator of price suitability with benefits, showing that the more suitability of Malabar Mountain Café in setting the selling price with the benefits were obtained from coffee products. Thus, consumer purchasing decisions would increase.

The price variable in this research was also reflected in the price affordability indicator. this showed that the more affordable prices set by Malabar Mountain Café, the more consumer purchasing decisions would be increased.

In this research, prices were also reflected in the indicator of price competitiveness. It showed that the more competitive prices set by Malabar Mountain Cafe with other coffee shops, the more consumer purchasing decisions will increase.

The variable price relation indicated that price was an important thing for Malabar Mountain Café consumers in making purchase decisions. Thus, it is expected that Malabar Mountain Café can maintain its price in order to compete with other coffee shops. The price offered by the Malabar Mountain Cafe was a consideration for consumers in making their purchases.

The price offered by Malabar Mountain Cafe for ready-to-drink coffee started from IDR 20,000 to IDR 60,000. The most expensive coffee price was Hot Siphon Black Coffee Luwak coffee. The roastedbean price of the Malabar Mountain Cafe started from IDR 60,000 to IDR 290,000. This price depended on the type of coffee processing and the weight of the coffee.
From this research, it was found that the pricing that would be offered to coffee consumers was very important. This statement was in line with the opinion of Tadjung (2004) that pricing is very important because consumers are increasingly critical and selective in spending money. In certain situations, consumers are very sensitive to price, hence, a relatively high price compared to its competitors can eliminate the product from consumer consideration (Kotler, 1993). In line with this statement, Malabar Mountain Café in determining the price of its coffee had to look at the conditions, demands and needs of its consumers. Therefore, consumers continued to choose Malabar Mountain Cafe as a place to purchase their coffee. The results of this research were also in accordance with the results of research by Saenewat Oetama (2011) stating that price has a relation with consumer purchasing decisions.

Promotion variable had a strong and significant relation with coffee consumer purchasing decisions. The correlation coefficient value was 0.353 and a significance value was $0.012(\mathrm{p}<0.05)$. Thus, it can be interpreted that the more the promotion mix is improved, the purchasing decisions will also increase

The promotion mix applied by Malabar Mountain Café was discounted prices, bonuses and also advertising activities. Promotional activities in the form of price discounts reflected that the more frequent price discounts were given, the consumer's purchasing decisions would increase. This discount was usually conducted when Malabar Mountain Café released a new product. Discounts were given up to 25-50 percent of the normal price. This aimed to introduce new products and attract consumers to buy with hope that consumers would repurchase later.

Promotional activities in the form of bonuses reflected the increased frequency of giving bonuses to consumers, the consumer's purchasing decisions would increase. The bonuses were given during the coffee exhibition activities at the coffee festival 
(exhibition coffee). Activities conducted during the exhibition were displaying Malabar Mountain Cafe arabica coffee from several processing processes, demonstration and presentation activities of making coffee with manual brew processes, in which the coffee drinks were distributed to consumers who visited the Malabar Mountain Cafe stand.

Promotional activities in this research were also reflected in advertising activities. It showed that the more frequent and more advertising activities were carried out, the consumer purchasing decisions would increase. Currently, Malabar Mountain Café was actively carrying out its advertising activities through social media. Malabar Mountain Café was actively uploading product photos, product videos and the state of Malabar Mountain Cafe. The Malabar Mountain Café had been followed by 6,264 people on their Instagram account. The main purpose of the promotion carried out by Malabar Mountain Cafe was to introduce coffee products, attract attention and encourage consumers to purchase coffee offered by Malabar Mountain Cafe.

Thus, the relation between promotion and consumer purchasing decisions in this research was in accordance with the opinion of Gitosudarmo (2000), that promotion is an activity aimed at influencing consumers, thus, they can become acquainted with the products offered by the company to them and then they become happy and buy the product.

The location variable had a significance value of $0.496(p>0.01)$. This showed that location had no relation with coffee consumer purchasing decisions. This was because Malabar Mountain Café was only available in one location in Bogor City on Jalan Dr. Sumeru. For consumers who really liked and were satisfied with Malabar Mountain Café both from the product, price or promotion, it would not matter where the Malabar Mountain Cafe was. Sarjono (2013) also argued that if the purchase of a good or service has been carried out in a company that results in customer satisfaction, the consumer does not question the company's existence. With this theory, it showed that the location of the Malabar Mountain Cafe had no relation to purchase decisions when consumers feel satisfied with their coffee purchases.

Hence, the mix of locations was not an important thing for consumers in making coffee purchasing decisions at Malabar Mountain Café. The results of this research were similar to research conducted by Desfita (2014) entitled "Analisis Hubungan Bauran Pemasaran dengan Keputusan Pembelian Smartphone Blackberry dan Samsung Android", in which there was no relation between location and purchase decisions.

\section{CONCLUSION}

From the description of the results of research about the relation between marketing mix and consumer purchasing decisions for coffee at Malabar Mountain Café in Bogor City, it can drawn the conclusion that:

Most consumers of Malabar Mountain Cafe live in Bogor City. They are dominated by men with a productive age of 25-35 years. Malabar Mountain Café's customers mostly work as private employees with monthly expenditure levels of more than IDR 3,000,000. Malabar Mountain Cafe consumers had more than eight times their weekly coffee consumption rate. Many Malabar Mountain Café's consumers make purchases by coming in person and for the first time knowing about Malabar Mountain Café from family or friends.

1. The implementation of the Malabar Mountain Cafe's marketing mix shows that the product mix has met the needs and desires of its consumers. In the price mix, the price set is in accordance with the conditions and expectations of its consumers. In the mix of locations, the location of Malabar Mountain Cafe is accessible and it has easy access. However, the promotional mix did not attract attention and encourage consumers to make purchases at Malabar Mountain Cafe. 
2. The relation between the marketing mix and coffee consumer purchasing decisions at Malabar Mountain Café is that the product has a strong relation with consumer's purchasing decisions of coffee and it ranks at the top. Price has a strong relation with consumers' purchasing decisions of coffee and it ranks second. Promotion has a strong enough relation with consumer purchasing decisions of coffee and it is ranked third and location has no relation with consumer purchasing decisions of coffee at the Malabar Mountain Café in Bogor City.

Based on the results of research on the relationship between marketing mix and consumer purchasing decisions for coffee at Malabar Mountain Cafe in Bogor City, there are several suggestions as input and consideration in making decisions that are beneficial to Malabar Mountain Cafe:

1. Malabar Mountain Café must be able to maintain the coffee products and prices because the product mix and prices have a strong level of relation to improve coffee consumer purchasing decisions.

2. Malabar Mountain Cafe needs to add to the promotion program. Promotions can be as follows; campaigning to buy 1 coffee for free 1 coffee, distributing giveaway, using the services of influencers who have an interest and understand about coffee, maintaining engagement with the coffee consumer community thereby increasing WOM (Word of Mouth) promotion.

\section{REFERENCES}

Desfita, I. 2014. Analisis hubungan bauran pemasaran terhadap keputusan pembelian smartphone blackberry dan samsung android. Jurnal Optimasi Sistem Industri 13 (2): 687-706.

Gitosudarmo. 2000. Manajemen Pemasaran. Edisi ke-1. Yogyakarta. BPFE.

Kotler, P. 2002. Manajemen Pemasaran. Edisi milenium. Jakarta. PT Prehalindo.

Kotler, P. 1993. Menejemen Pemasaran,
Perencanaan, Implementasi dan Kontrol. Jakarta. PT Rosdakarya.

Maholtra, N. K. 2010. Riset Pemasaran. Jakarta. PT Indeks Kelompok Gramedia.

Prayogo, H. and E. R. Lumowa. 2008. Pengaruh faktor dan pelayanan terhadap loyalitas konsumen Restoran Kapin Raya Kupang Indah Surabaya. Thesis. Universitas Kristen Petra. Surabaya.

Santoso, A. and S. Y. Widowati. 2011. Pengaruh kualitas layanan, fasilitas dan lokasi terhadap keputusan pembelian (Studi kasus Pada Kopma USM). Jurnal Dinamika Sosial Budaya 13(2): 179-190.

Sarjono, B. 2013. Analisis pengaruh bauran pemasaran produk, harga, lokasi terhadap minat beli ulang. Orbith 9(3): 228-235.

Sarwono, J. and E. Suhayati. 2010. Riset Akuntansi Menggunakan SPSS. Jakarta. Erlangga.

Sugiyono. 2013. Metode penelitian Kuantitatif, Kualitatif dan R\&D. Bandung. Alfabeta.

Tandjung. 2004. Marketing Management: Pendekatan pada Nilai-nilai Pelanggan. Edisi kedua. Malang. Penerbit Bayumedia.

Toffin. 2019. Riset toffin: Bisnis kedai kopi makin menggeliat di 2019. Retrieved from

https://www.industry.co.id/read/58786/ riset-toffin-bisnis-kedai-kopi-makinmenggeliat-di-2019.

Tripadvisor. 2019. Kafe di Bogor. Retrieved from

https://www.tripadvisor.co.id/Restaura nts-g297706-c8-

Bogor_West Java Java.html 